\title{
Relationship between train users' perceptions of walkability with access and egress mode choice
}

\author{
Romeiza Syafriharti ${ }^{1, *}$, B. Kombaitan ${ }^{2}$, Iwan P. Kusumantoro ${ }^{3}$, and Ibnu Syabri ${ }^{2}$ \\ ${ }^{1} \mathrm{PhD}$ Student of Transportation, SAPPK, Institut Teknologi Bandung, Bandung, Indonesia \\ ${ }^{2}$ Urban and Regional Planning, SAPPK, Institut Teknologi Bandung, Bandung, Indonesia \\ ${ }^{3}$ Transportation, SAPPK, Institut Teknologi Bandung, Bandung, Indonesia
}

\begin{abstract}
The purpose of this study is to understand whether there is a relationship between train users' perceptions of walkability in built environment of trip origin with access mode choice and between train users' perceptions of walkability in built environment of trip destination with egress mode choice. Train users are who ride from Cicalengka station Bandung Regency, West Java, Indonesia. To analyze the relationship is used crosstab method. The perceptual factors about walkability are those perceived by the train users consisting of walking distance, safety, comfort, and secure from crime, both in origin and destination of the built environment. The mode choice consist of walking, paratransit, motorcycle taxi, and own vehicles (or others for egress mode). To better understand the relationship is used several control variables, that are trip purposes, train usage, gender, and age. For access trip there is another control variable, that is vehicle ownership. Train users' perceptions of walkability have a relationship with both the access and the egress mode choice, except for the security aspect. The influence of control variables on the relationship between perceptions of walkability with access/egress mode choice varies for walking distance, safety, and comfort.
\end{abstract}

\section{Introduction}

Walking as transport mode has been extensively researched from various fields of science, not only directly related to transportation itself, but also from the urban design, urban planning, and even linked to health. The decision to walk as a transport mode can be influenced by many factors, among which many of the research findings are a good walkability of the built environment.

To decide whether to walk or not to/from transit, the measurement of walkability that is researched varies considerably. Among these measures there is a focus on walking distance [1-3]. Distance to transit together with density, diversity, (street) design, and distance to destination are an urban form attributes known as 5 D's used when verify the effect of built environment on walking and cycling [4]. In addition, there is also evidence of the effects of 3 D's urban forms, that are density, diversity, and design (street network design), for walking to transit [5]. Meanwhile, also there are the effects of urban design attributes on walking as access mode to the station [6]. Only walking distance is not enough to analyze walking to transit required more than that, ie walking effort or walking accessibility [7]. Later, psychological factors are used to measure walkability and verify the effect on walking or using vehicles to public transport facilities, such as enjoyment of walking and social pressure [8]. From previous studies, it appears that, in examining the effect of built environments walkability in the choice of walking as access/egress mode to/from transit there is a variety of walkability measures.

In recent years, research on the mode choice of transport, including walking, tends to consider soft variables or subjective variables [9]. The residential environment determines the choice of mode rather than the objective characteristics of the built environment [10]. It is aligned with other studies that include self-selection variables in analysis the relationship between the built environment and travel behaviour, especially walking [11, 12].

Research that take into account travelers' perceptions of built environment walkability and examine their relationship with mode choice is still limited in number. Most studies use objective walkability measurements, such as by using urban form or urban design attributes. Research using subjective walkability measurement are still limited to the perceptions of built environment walkability in residence neighborhood only and just few about built environment walkability in place of activity, like at work place.

For public transport users, good walkability is not only important in the precincts of the residence to/from public transport facilities, but also around the site of activities to/from public transport facilities. Based on the findings of previous studies, that the subjective measurement of walkability relative to the greater effect on the mode choice than the objective measurement, the perceptions of

* Corresponding author: romeiza.syafriharti@email.unikom.ac.id 
travelers is used as a measure of walkability. Walkability at the start of the journey (start miles) may be different from walkability at the end of the journey (end miles), as well as the mode used may vary between access mode and egress mode.

The object of this research is Bandung Raya railway users who ride from Cicalengka train station in Bandung Regency West Java Province Indonesia and reside around the station. The destination railway stations are spread from Rancaekek to Padalarang. Therefore, this research aims to explore the relationship between railway users' perceptions about walkability with the choice of modes, specifically to answer the following research questions:

- Is there a relation between rail users' perceptions of the built environment walkability from residence to the origin railway station (during the access trip) with the access mode choice; and

- Is there a relation between railway users' perceptions of the built environment walkability from the destination railway station to the activity place (during egress trip) with the egress mode choice.

Basically, what is meant by access mode is a mode used to get from a trip origin (in this case is home) to a main mode (rail station origin), and vice versa (returning trip). While egress mode is a mode used to get from the main mode (destination train station) to the trip destination, and vice versa (returning trip) which can be seen on Fig. 1. The mode used on the returning trip may vary with the mode on the access trip. The same condition can also occur in egress trips. Therefore, in this research, access trip are limited only to travel from home to origin station, while the egress trip is a trip from the destination station to the final destination (Fig.2), excluding the returning trip. Access trip is distinguished by egress trip. On access trip there is a chance to use private vehicle, because the journey starts from home. While on egress trip there is no possibility of using private vehicles. With good walkability then walking is expected to be chosen as access and egress mode.

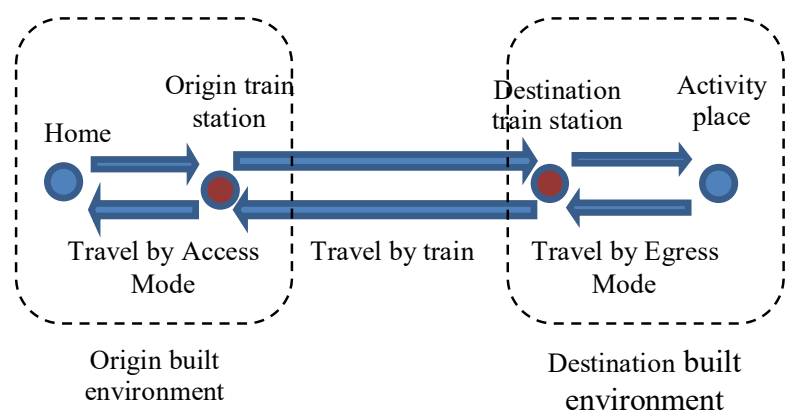

Fig. 1. General scheme of railway user travel.

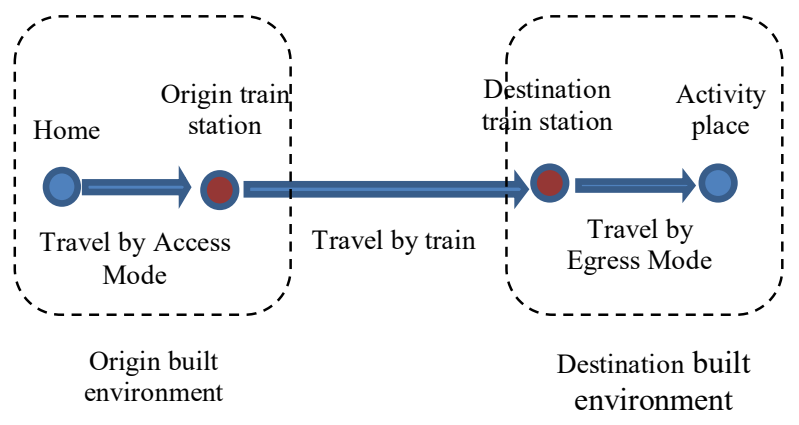

Fig. 2. Railway user travel scheme for this research.

\section{Literature Review}

In the process of this research, it's conducted literature review of related research on walking behavior that are influenced by the existence of psychological factors in assessing the built environment. Not much literatures are found which deals with walking as access mode and also as egress mode. Therefore, the reviewed research are walking as the whole transport mode, not only as access/egress mode but also walking as main mode. In the following table can be seen some previous research that explore the relationship between perceptions of built environment walkability with walking behavior.

From the previous research, there are some variables that are most widely analyzed. One of them is variable related to walking distance. This variable is defined as one that will be assessed by the train users who will ride from Cicalengka train station. Other variables to be considered are safety, comfort, and security.

- Walking distance

Walking distance contains complex notions, so it is not enough to be represented only by physical distance, but more precisely defined as walking effort [7] or walking accessibility. The perceived walking distance can vary for the actual distance [2]. Therefore, for walkability, walking distance is more appropriate if using pedestrian perceptions.

- Safety from motorized-vehicle traffic

Safety from vehicle traffic is also one of the variables whose judgments can be different for everyone. Especially if that walk are children or old people, safety standards will be different from adults or who do not have certain limitations. Safety perceptions from vehicle traffic in the built environment significantly influences walking as transport mode $[11,16]$. Although traffic volume can be calculated to get the actual amount of traffic, still the perceptions of safety can vary for each person.

- Comfort

Comfort is an abstract measurement, although it can be realized through the urban design attributes. The meaning of comfort is also contained in the 'spaciousness' [11], 'convenience' [8], 'aesthetics' [14], 'walkway width' and 'walkway quality' [15], 'quietness' [10], and even 'green streets' [16]. Such a broadness of meaning is contained in 'comfort'. 'Comfort' is something that is perceived, then for this 
variable is more precisely measured subjectively from pedestrian.

- Security from crime

Security is one of the basic requirements of transportation. However, in research on walkability, not many use it as the main variable. Most are part of attitudes [11].

Table 1. A summary of some previous research on the relationship between perceptions of built environment walkability with walking behaviour.

\begin{tabular}{|c|c|c|c|c|}
\hline $\begin{array}{l}\text { Researcher, Trip } \\
\text { Purposes, Location }\end{array}$ & Methods & $\begin{array}{c}\text { Walking Behavior } \\
\text { Variables }\end{array}$ & $\begin{array}{c}\text { Perceptions of Built } \\
\text { Environment } \\
\text { Walkability Variables }\end{array}$ & Results \\
\hline $\begin{array}{l}\text { Handy et al., } 2006 \text { [11] } \\
\text { Traditional dan } \\
\text { suburban } \\
\text { neighborhood } \\
\text { Northern California }\end{array}$ & $\begin{array}{l}\text { Negative binomial } \\
\text { regression } \\
\text { Cross-sectional analysis } \\
\text { Quasi-longitudinal } \\
\text { analysis }\end{array}$ & $\begin{array}{l}\text { Walking as transport } \\
\text { mode }\end{array}$ & $\begin{array}{l}\text { Accesibility, physical } \\
\text { activity option, safety, } \\
\text { socializing, outdoor } \\
\text { spaciousness, } \\
\text { attractiveness }\end{array}$ & $\begin{array}{l}\text { Built environment has } \\
\text { an impact on walking } \\
\text { behavior even after } \\
\text { accounting for attitudes } \\
\text { and preferences. }\end{array}$ \\
\hline $\begin{array}{l}\text { Mehta, } 2008[13] \\
\text { All purposes } \\
\text { Main street in Boston }\end{array}$ & $\begin{array}{l}\text { Qualitative studies for } \\
\text { microscale analysis }\end{array}$ & $\begin{array}{l}\text { Walking as transport } \\
\text { mode }\end{array}$ & $\begin{array}{l}\text { Usefulness, safety, } \\
\text { comfort, pleasurability, } \\
\text { sense of belonging }\end{array}$ & $\begin{array}{l}\text { Usefulness, sense of } \\
\text { belonging and } \\
\text { pleasurability were } \\
\text { most important. }\end{array}$ \\
\hline $\begin{array}{l}\text { Walton \& Sunseri, } \\
2010[8] \\
\text { All purposes } \\
\text { Auckland \& } \\
\text { Wellington }\end{array}$ & ANOVA \& ANCOVAs & $\begin{array}{l}\text { Walking as access } \\
\text { mode, besides drive }\end{array}$ & $\begin{array}{l}\text { Fear of crime, } \\
\text { distance/time, parking } \\
\text { charges, inconvenience, } \\
\text { and non built } \\
\text { environment variables }\end{array}$ & $\begin{array}{l}\text { Distance, fear of crime } \\
\text { and time do not affect } \\
\text { walking. }\end{array}$ \\
\hline $\begin{array}{l}\text { Panter \& Jones, } 2010 \\
{[14]} \\
\text { Adults for active } \\
\text { transport }\end{array}$ & $\begin{array}{l}\text { Quantitative studies } \rightarrow \\
\text { review previous studies } \\
\text { by examining the } \\
\text { influence of } \\
\text { psychological and } \\
\text { environmental factors }\end{array}$ & $\begin{array}{l}\text { Walking or cycling as } \\
\text { transport mode }\end{array}$ & $\begin{array}{l}\text { Functional } \\
\text { (infrastructure \& street } \\
\text { connectivity), Safety, } \\
\text { Aesthetics, } \\
\text { Destinations (facility } \\
\text { provision, residential } \\
\text { density, land usemix, } \\
\text { coastal proximity, } \\
\text { walkable environment }\end{array}$ & $\begin{array}{l}\text { Walking or cycling } \\
\text { associated with only } \\
\text { psychological } \\
\text { factors or with only } \\
\text { built environment } \\
\text { factors or with both of } \\
\text { them }\end{array}$ \\
\hline $\begin{array}{l}\text { Lin \& Yu, } 2011 \text { [15] } \\
\text { Leisure travel } \\
\text { Students of elementary } \\
\text { schools } \\
\text { In the Shilin District of } \\
\text { Taipei }\end{array}$ & $\begin{array}{l}\text { Negative binomial } \\
\text { regression model } \\
\text { Multinomial logit } \\
\text { model }\end{array}$ & $\begin{array}{l}\text { Walking as transport } \\
\text { mode, besides cycling } \\
\text { and public transport }\end{array}$ & $\begin{array}{l}\text { Walkway width, } \\
\text { walkway quality, } \\
\text { safety, and other } \\
\text { variables (non- } \\
\text { perceptions variables) }\end{array}$ & $\begin{array}{l}\text { From perceptions } \\
\text { variables, walkway } \\
\text { quality encouraged a } \\
\text { child to walk. }\end{array}$ \\
\hline $\begin{array}{l}\text { Adkins et al., } 2012 \\
{[16]} \\
\text { All purposes } \\
\text { Residential } \\
\text { neighborhood in } \\
\text { Portland, Oregon } \\
\end{array}$ & OLS & $\begin{array}{l}\text { Walking as transport } \\
\text { mode }\end{array}$ & $\begin{array}{l}\text { Street characteristics, } \\
\text { Adjacent land use, } \\
\text { Pedestrian } \\
\text { environment, Safety } \\
\text { interventions, Green } \\
\text { streets }\end{array}$ & $\begin{array}{l}\text { Green street facilities, } \\
\text { safety, and pedestrian } \\
\text { network connectivity } \\
\text { contribute to walking } \\
\text { environment } \\
\text { attractiveness. }\end{array}$ \\
\hline $\begin{array}{l}\text { Van Acker et al., } 2013 \\
{[10]} \\
\text { Leisure trips } \\
\text { Belgium: urban, } \\
\text { suburban, rural }\end{array}$ & $\begin{array}{l}\text { Factor and cluster } \\
\text { analysis }\end{array}$ & $\begin{array}{l}\text { Walking (and cycling) } \\
\text { as transport mode, } \\
\text { besides car and public } \\
\text { transport }\end{array}$ & $\begin{array}{l}\text { Close to public } \\
\text { transport, Close to } \\
\text { shop, Quietness, } \\
\text { Presence of green } \\
\text { areas, Close to leisure } \\
\text { activities, Close to } \\
\text { family and friends, } \\
\text { Close to work }\end{array}$ & $\begin{array}{l}\text { Walkability } \\
\text { perceptionss affect the } \\
\text { population in the } \\
\text { suburb. }\end{array}$ \\
\hline $\begin{array}{l}\text { Hernández \& Witter, } \\
2015 \text { [2] } \\
\text { All purposes } \\
\text { Santiago de Chile }\end{array}$ & $\begin{array}{l}\text { Comparative analysis } \\
\rightarrow \text { Perceived vs. Actual } \\
\text { distance to transit }\end{array}$ & $\begin{array}{l}\text { Walking as access } \\
\text { mode }\end{array}$ & $\begin{array}{l}\text { Walking distance to } \\
\text { public transport station } \\
\text { (buses and metro) }\end{array}$ & $\begin{array}{l}\text { Metro supply has a } \\
\text { higher overestimation } \\
\text { rate than buses. }\end{array}$ \\
\hline
\end{tabular}




\section{Methods}

Respondents are train users who ride from Cicalengka train station and who live around that train station (1000 $\mathrm{m}$ radius). Of the nearly 300 completed questionnaires only 203 sets of data can be processed. There are other requirements set for the selection of respondents, which are restricted to those aged 17 years or older. The consideration is to be consistent with the classification of trip purposes, one of which is to work. The survey was conducted on weekdays (Monday - Wednesday) for train departures at 06.15, 07.25, 09.00, and 09.45. Questionnaires were mostly filled by respondents on trains with the help of surveyors, few succeeded in filling out questionnaires at railway stations.

Each respondent was asked the usual mode of transportation for access trip from home to Cicalengka train station and for egress trip from destination train station to activity location (final destination). Each respondent also asked about the perceptions of walkability from home to Cicalengka train station, which is related to walking distance, safety from motorized vehicle, comfort, and security from crime. Perceptions of walkability from station of destination to final destination are also asked. For all questions relating to walkability perceptions, ie 'distance', 'safety', 'comfort', and 'security', respondents are required to provide an assessment of the requested agreement on 5-point Likert Scale from "strongly agree to strongly disagree". Thus, the perceptions of walkability in this research is what train users perceived about distance, safety, comfort and security in the built environment at the beginning of the journey and at the end of the journey.

In addition, respondents also filled out data on travel characteristics and socio-economic characteristics. These variables are as control variables when analyze the relationship between walkability perceptions from home to origin station with access mode and between walkability perceptions from destination station to final destination with egress mode. Characteristics of the trip consists of trip purposes and frequency of train usage. While socio-economic characteristics consist of gender, age, and vehicle ownership.

All data from all variables are ordinal data, including control variables. Because the focus of research is walkability and walking as transport mode, then for all control variables, the largest value as ordinal data is given to the most likely to choose walking as transport mode. For example, in the ownership of vehicle variable, the value 1 is given to those who do not have the opportunity to use own vehicles, so the chances of walking to the railway station are greater than those that have the option of using own vehicles. While the value 0 is given to who owns a private vehicle. For egress trips, ownership vehicle variables are not tested as control variables because there is no opportunity to use own vehicles from destination stations to final destinations.

The same assumption is used for other variables, which is assumed to have a greater chance of choosing walking on the access or egress trip, given a larger value (see Table 2). These assumptions are for trip purposes 'work', train usage 'very often', gender 'male', age group ' $17-25$ years', and ownership vehicle 'no' is assumed to be most likely to choose walking as access or egress mode compared the other groups.

For train usage characteristics used 5 point scale, from very often to very rarely. The grouping of train usage is very rarely $=1$ (once in more than 2 months), rarely $=2$ (once in 2 months), not too often $=3$ (once or twice a month), often $=4$ (once or twice a week), and very often $=5$ (almost every day).

Table 2. Variables.

\begin{tabular}{|l|}
\hline \multicolumn{1}{|c|}{ Main Variables } \\
\hline Walkability \\
Walking distance \\
Safety from motorized vehicle traffic \\
Comfort \\
Security from crime \\
$\quad 5$ point scale from strongly agree to strongly \\
disagree)
\end{tabular}

Data is divided into two sets of data, which are related to access trip and related to egress trip. To find the relationship between all aspects of walkability perceptions with access/egress mode, cross tabulation analysis was used, both for walking distance, safety, comfort, and security, with significance level $(\alpha)=5 \%$. SPSS is used for data processing and analysis. Thus, HO will be rejected if the probability (value of Asymp .Sig. (2-sided) $<0.05$, which means there is a relationship between the variables tested. For evaluate the strength of correlation is used Spearman Correlation value because all data are ordinal.

\section{Results}

\subsection{Access and egress mode}

From percentage of mode share, paratransit is the most preferred mode, both for access trip and egress trip. The difference is if the access trip is also dominant mode in addition to the paratransit is own vehicle, while the egress trip is paratransit and walking. Can be seen the difference of mode share on access trip with egress trip. The 
percentage of walking on the egress trip is greater than in the access trip. Apparently, own vehicle and motorcycle taxi users on access trip prefer walking and paratransit on egress trip.

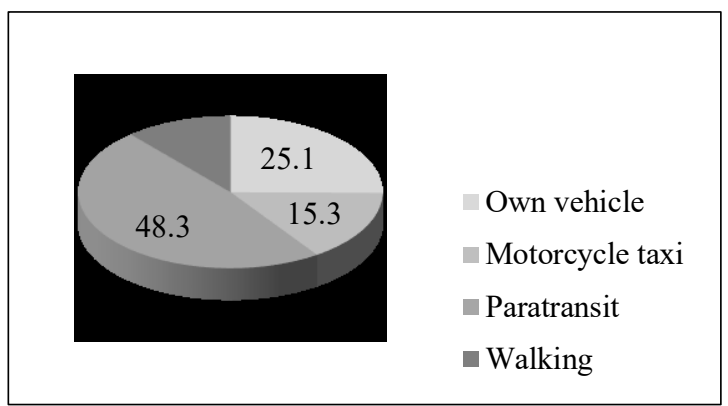

Fig. 3. Mode share percentage of access trip.

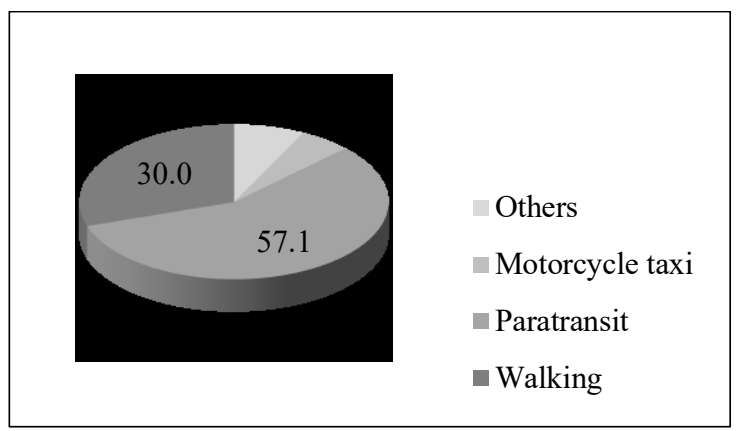

Fig. 4. Mode share percentage of egress trip.

\subsection{Perceptions of walkability}

In general, the perceptions of walkability is good, both for walkability from home to origin rail station and from destination rail station to final destination. The 'strongly disagree' answer is relatively small in number, even for walkability in destination built environment the 'strongly disagree' answers are not available for safety from motorized-vehicle traffic and security from crime.

Table 3. Percentage of respondents based on perceptions of built environment walkability.

\begin{tabular}{|l|c|c|c|c|c|}
\hline & $\mathbf{1}$ & $\mathbf{2}$ & $\mathbf{3}$ & $\mathbf{4}$ & $\mathbf{5}$ \\
\hline \multicolumn{5}{|c|}{ From home to origin station } \\
\hline $\begin{array}{l}\text { Walking } \\
\text { distance }\end{array}$ & 4.93 & 28.57 & 25.12 & 25.12 & 16.26 \\
\hline $\begin{array}{l}\text { Safety from } \\
\text { motorized- } \\
\text { vehicle traffic }\end{array}$ & 1.97 & 7.88 & 29.56 & 45.81 & 14.78 \\
\hline Comfort & 1.97 & 8.87 & 31.03 & 47.29 & 10.84 \\
\hline $\begin{array}{l}\text { Security from } \\
\text { crime }\end{array}$ & 0.99 & 9.85 & 29.06 & 41.38 & 18.72 \\
\hline \multicolumn{7}{|c|}{ From destination station to end destination } \\
\hline $\begin{array}{l}\text { Walking } \\
\text { distance }\end{array}$ & 7.88 & 18.72 & 25.12 & 36.95 & 11.33 \\
\hline $\begin{array}{l}\text { Safety from } \\
\text { motorized- } \\
\text { vehicle traffic }\end{array}$ & 0.00 & 7.88 & 33.99 & 46.31 & 11.82 \\
\hline Comfort & 0.49 & 2.46 & 34.48 & 46.31 & 16.26 \\
\hline
\end{tabular}

\begin{tabular}{|c|c|c|c|c|c|}
\hline & 1 & 2 & 3 & 4 & 5 \\
\hline $\begin{array}{l}\text { Security from } \\
\text { crime }\end{array}$ & 0.00 & 10.34 & 31.53 & 41.38 & 16.75 \\
\hline $\begin{array}{l}\text { Note: } \\
1=\text { Strongly disagr } \\
2=\text { Disagree } \\
3=\text { Ordinary } \\
4=\text { Agree } \\
5=\text { Strongly agree }\end{array}$ & & & & & \\
\hline
\end{tabular}

Except for walking distance in the origin built environment, the perceptions of safety, comfort, and security are mostly agree. While the perception of walking distance in the origin built environment is almost balanced between disagree, ordinary, and agree. So, among the four components of the perceptions of walkability assessment, 'walking distance' earns the lowest rating compared to the other components.

\subsection{Travel characteristics}

Among the classification of trip purposes the most is to 'work', then 'others'. As for 'school' and 'shopping' is not too dominant for travel using the train from Cicalengka station. When viewed from the number of respondents with trip purposes other than for 'work', 'school', and 'shopping' (others), reaching $29.06 \%$. This number is large enough that it seems that a more detailed classification of trip purposes is needed for future research.

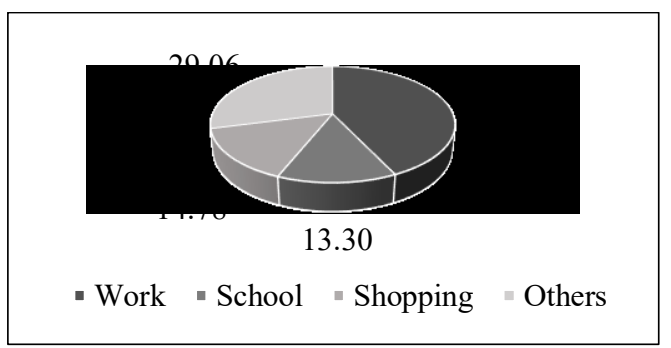

Fig. 5. Percentage of trip purposes.

When viewed from the railway usage level, about $60 \%$ of respondents answered 'often' and 'very often' which can be categorized as regular train users. However, as many as $30 \%$ of rail users are users who belong to the category 'rarely' and 'very rarely'.

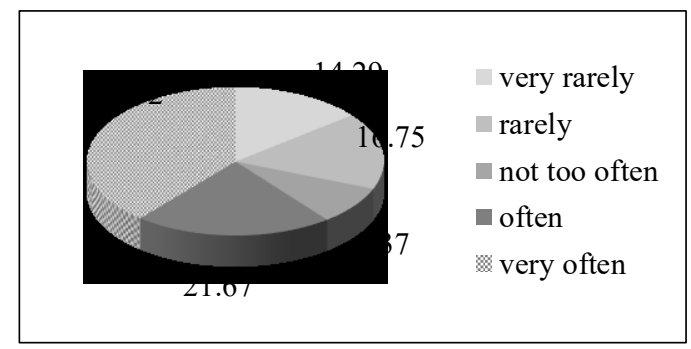

Fig. 6. Percentage of train usage. 


\subsection{Socio-economics characteristics}

The number of male passengers is slightly higher than that of female. Whereas by age group, only a few are aged 50 years and over. Most of them have vehicles, whether they are motorcycles or cars, which are likely to be used for travel from home to the origin station.

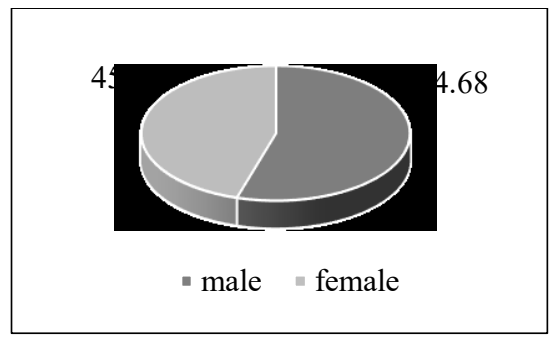

Fig. 7. Percentage of gender.

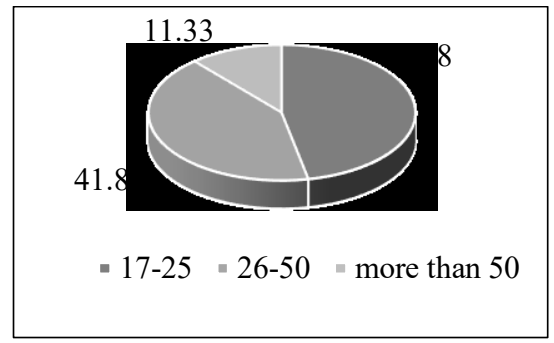

Fig. 8. Percentage of age group.

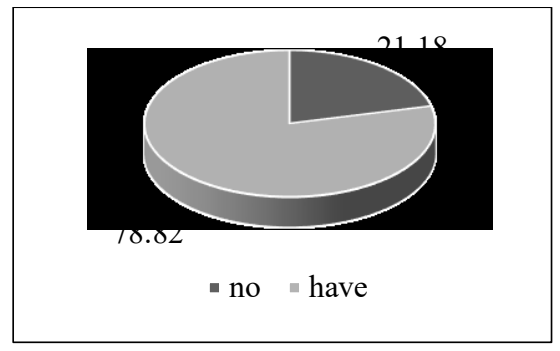

Fig. 9. Percentage of vehicle ownership.

\subsection{Relationship analysis}

Furthermore, it will be analyzed whether there is a relationship between walkability with mode choice, and also analyzed whether there is influence of each control variable on the relationship. Relationship analysis is performed for each walkability component, ie walking distance, safety from motorized vehicle traffic, comfort, and security from crime, with hypotheses such as Table 4.

Table 4. Hypotheses.

\begin{tabular}{|c|l|}
\hline No. & \multicolumn{1}{|c|}{$\mathbf{H}_{\mathbf{0}}$} \\
\hline \multicolumn{1}{|c|}{$\mathbf{H}_{\mathbf{0}}$ for Access Trip } \\
\hline 1. & $\begin{array}{l}\text { There is no relationship between perceptions of } \\
\text { walking distance and access mode choice. }\end{array}$ \\
\hline 2. & $\begin{array}{l}\text { Trip purposes have no effect on the relationship } \\
\text { between perceptions of walking distance and access } \\
\text { mode choice. }\end{array}$ \\
\hline
\end{tabular}

\begin{tabular}{|c|c|}
\hline No. & $\mathbf{H}_{0}$ \\
\hline 3. & $\begin{array}{l}\text { Train usage have no effect on the relationship between } \\
\text { perceptions of walking distance and access mode } \\
\text { choice. }\end{array}$ \\
\hline 4. & $\begin{array}{l}\text { Gender have no effect on the relationship between } \\
\text { perceptions of walking distance and access mode } \\
\text { choice. }\end{array}$ \\
\hline 5. & $\begin{array}{l}\text { Age have no effect on the relationship between } \\
\text { perceptions of walking distance and access mode } \\
\text { choice. }\end{array}$ \\
\hline 6. & $\begin{array}{l}\text { Vehicle ownership have no effect on the relationship } \\
\text { between perceptions of walking distance and access } \\
\text { mode choice. }\end{array}$ \\
\hline 7. & $\begin{array}{l}\text { There is no relationship between perceptions of safety } \\
\text { from motorized vehicle traffic and access mode } \\
\text { choice. }\end{array}$ \\
\hline 8. & $\begin{array}{l}\text { Trip purposes have no effect on the relationship } \\
\text { between perceptions of safety from motorized vehicle } \\
\text { traffic and access mode choice. }\end{array}$ \\
\hline 9. & $\begin{array}{l}\text { Train usage have no effect on the relationship between } \\
\text { perceptions of safety from motorized vehicle traffic } \\
\text { and access mode choice. }\end{array}$ \\
\hline 10. & $\begin{array}{l}\text { Gender have no effect on the relationship between } \\
\text { perceptions of safety from motorized vehicle traffic } \\
\text { and access mode choice. }\end{array}$ \\
\hline 11. & $\begin{array}{l}\text { Age have no effect on the relationship between } \\
\text { perceptions of safety from motorized vehicle traffic } \\
\text { and access mode choice. }\end{array}$ \\
\hline 12. & $\begin{array}{l}\text { Vehicle ownership have no effect on the relationship } \\
\text { between perceptions of safety from motorized vehicle } \\
\text { traffic and access mode choice. }\end{array}$ \\
\hline 13. & $\begin{array}{l}\text { There is no relationship between perceptions of } \\
\text { comfort for walking with access mode choice. }\end{array}$ \\
\hline 14. & $\begin{array}{l}\text { Trip purposes have no effect on the relationship } \\
\text { between perceptions of comfort for walking with } \\
\text { access mode choice. }\end{array}$ \\
\hline 15. & $\begin{array}{l}\text { Train usage have no effect on the relationship between } \\
\text { perceptions of comfort for walking with access mode } \\
\text { choice. }\end{array}$ \\
\hline 16. & $\begin{array}{l}\text { Gender have no effect on the relationship between } \\
\text { perceptions of comfort for walking with access mode } \\
\text { choice. }\end{array}$ \\
\hline 17. & $\begin{array}{l}\text { Age have no effect on the relationship between } \\
\text { perceptions of comfort for walking with access mode } \\
\text { choice. }\end{array}$ \\
\hline 18. & $\begin{array}{l}\text { Vehicle ownership have no effect on the relationship } \\
\text { between perceptions of comfort for walking with } \\
\text { access mode choice. }\end{array}$ \\
\hline 19. & $\begin{array}{l}\text { There is no relationship between the perceptions of } \\
\text { security from crime and the access mode choice. }\end{array}$ \\
\hline 20. & $\begin{array}{l}\text { Trip purposes have no effect on the relationship } \\
\text { between perceptions of security from crime and access } \\
\text { mode choice. }\end{array}$ \\
\hline 21. & $\begin{array}{l}\text { Train usage have no effect on the relationship between } \\
\text { perceptions of security from crime and access mode } \\
\text { choice. }\end{array}$ \\
\hline 22. & $\begin{array}{l}\text { Gender have no effect on the relationship between } \\
\text { perceptions of security from crime and access mode } \\
\text { choice. }\end{array}$ \\
\hline 23. & $\begin{array}{l}\text { Age have no effect on the relationship between } \\
\text { perceptions of security from crime and access mode } \\
\text { choice. }\end{array}$ \\
\hline 24. & $\begin{array}{l}\text { Vehicle ownership have no effect on the relationship } \\
\text { between perceptions of security from crime and access } \\
\text { mode choice. }\end{array}$ \\
\hline & $\mathrm{H}_{0}$ for Eggres Trip \\
\hline
\end{tabular}




\begin{tabular}{|c|c|}
\hline So. & \\
\hline 1. & $\begin{array}{l}\text { There is no relationship between perceptions } \\
\text { walking distance and egress mode choice. }\end{array}$ \\
\hline 2. & $\begin{array}{l}\text { Trip purposes have no effect on the relationship } \\
\text { between perceptions of walking distance and egress } \\
\text { mode choice. }\end{array}$ \\
\hline 3. & $\begin{array}{l}\text { Train usage have no effect on the relationship between } \\
\text { perceptions of walking distance and egress mode } \\
\text { choice. }\end{array}$ \\
\hline 4. & $\begin{array}{l}\text { Gender have no effect on the relationship between } \\
\text { perceptions of walking distance and egress mode } \\
\text { choice. }\end{array}$ \\
\hline 5. & $\begin{array}{l}\text { Age have no effect on the relationship between } \\
\text { perceptions of walking distance and egress mode } \\
\text { choice. }\end{array}$ \\
\hline 6. & $\begin{array}{l}\text { here is no relationship between perceptions of safety } \\
\text { om motorized vehicle traffic and egress mode choice. }\end{array}$ \\
\hline 7. & ohicle \\
\hline 8. & $\begin{array}{l}\text { ect on the relationship between } \\
\text { rom motorized vehicle traffic }\end{array}$ \\
\hline 9. & $\begin{array}{l}\text { t on the relat } \\
\text { from motorize } \\
\text { e. }\end{array}$ \\
\hline 10 . & $\begin{array}{l}\text { on the relationship between } \\
\text { y from motorized vehicle traffic } \\
\text { ice. }\end{array}$ \\
\hline 11. & $\begin{array}{l}\text { hip between perceptions of } \\
\text { h egress mode choice. }\end{array}$ \\
\hline 12. & $\begin{array}{l}\text { ns of comf } \\
\text { e. }\end{array}$ \\
\hline 13. & $\operatorname{Tr}$ \\
\hline 14. & tetween \\
\hline 15. & $\begin{array}{l}\text { Age have no effect on the } \\
\text { perceptions of comfort for walk }\end{array}$ \\
\hline 16. & in hetwe \\
\hline 17. & eptions of security from crime and egress \\
\hline 18. & have no effect on the \\
\hline 19. & $\begin{array}{l}\text { Gender have no effect on the relationship between } \\
\text { perceptions of security from crime and egress mode } \\
\text { choice. }\end{array}$ \\
\hline 20 & $\begin{array}{l}\text { Age have } n \\
\text { perceptions } \mathrm{C}\end{array}$ \\
\hline
\end{tabular}

As an alternative hypothesis, for every $\mathrm{H} 0$ is formulated $\mathrm{H}_{1} . \mathrm{H}_{1}$ is a hypothesis that states there is a relationship between variables tested. $\mathrm{H}_{1}$ is also formulated to test the influence of control variables on the relationship of the variables tested.

From the results of relationship analysis, for access trip there are 13 pairs of related variables and some of which have influence from control variables. Meanwhile, for egress trip only 3 pairs of related variables. Overall, it can be seen that the perceptual factors of walkability in the built environment at the origin of the journey are pretty much related to the mode choice, in this case the access mode choice. In contrast, the perceptions of walkability in the built environment at the end of the trip is not much related to egress mode choice (see Table 5). Although the correlation between related variables is not very strong, but the relationship is significant.

Table 5. The result of analysis.

\begin{tabular}{|c|c|c|c|}
\hline No. & $\begin{array}{l}\text { Variables that } \\
\text { are Related }\end{array}$ & $\begin{array}{l}\text { Asymp. Sig. } \\
\text { (2-sided) }\end{array}$ & $\begin{array}{l}\text { Correlation } \\
\text { (Spearman } \\
\text { Correlation } \\
\end{array}$ \\
\hline \multicolumn{4}{|c|}{ Access Trip } \\
\hline 1. & $\begin{array}{l}\text { Walking distance } \\
\text { - access mode } \\
\text { choice }\end{array}$ & 0.002 & 0.188 \\
\hline 2. & $\begin{array}{l}\text { Walking distance } \\
\text { - access mode } \\
\text { choice, } C V \text { : work }\end{array}$ & 0.000 & 0.438 \\
\hline 3. & $\begin{array}{l}\text { Walking distance } \\
\text { - access mode } \\
\text { choice, CV: very } \\
\text { often }\end{array}$ & 0.001 & 0.420 \\
\hline 4. & $\begin{array}{l}\text { Walking distance } \\
\text { - access mode } \\
\text { choice, } \mathrm{CV} \text { : male }\end{array}$ & 0.036 & 0.334 \\
\hline 5. & $\begin{array}{l}\text { Walking distance } \\
\text { - access mode } \\
\text { choice, CV: } 17-25 \\
\text { years }\end{array}$ & 0.016 & 0.081 \\
\hline 6. & $\begin{array}{l}\text { Walking distance } \\
\text { - access mode } \\
\text { choice, CV: have } \\
\text { (vehicle } \\
\text { ownership) }\end{array}$ & 0.008 & 0.174 \\
\hline 7. & $\begin{array}{l}\text { Safety - access } \\
\text { mode choice, CV: } \\
\text { female }\end{array}$ & 0.032 & 0.110 \\
\hline 8. & $\begin{array}{l}\text { Comfort }- \text { access } \\
\text { mode choice }\end{array}$ & 0.004 & 0.186 \\
\hline 9. & $\begin{array}{l}\text { Comfort - access } \\
\text { mode choice, CV: } \\
\text { work }\end{array}$ & 0.004 & 0.277 \\
\hline 10. & $\begin{array}{l}\text { Comfort - access } \\
\text { mode choice, } \mathrm{CV} \text { : } \\
\text { very often }\end{array}$ & 0.005 & 0.258 \\
\hline 11. & $\begin{array}{l}\text { Comfort - access } \\
\text { mode choice, CV: } \\
\text { female }\end{array}$ & 0.001 & 0.324 \\
\hline 12. & $\begin{array}{l}\text { Comfort }- \text { access } \\
\text { mode choice, } \mathrm{CV} \text { : } \\
26-50 \text { years }\end{array}$ & 0.006 & 0.246 \\
\hline 13. & $\begin{array}{l}\text { Comfort - access } \\
\text { mode choice, CV: } \\
\text { have (vehicle } \\
\text { ownership) }\end{array}$ & 0.010 & 0.185 \\
\hline \multicolumn{4}{|c|}{ Egress Trip } \\
\hline 14. & $\begin{array}{l}\text { Walking distance } \\
\text { - egress mode } \\
\text { choice }\end{array}$ & 0.024 & 0.230 \\
\hline 15. & $\begin{array}{l}\text { Safety - egress } \\
\text { mode choice, } \mathrm{CV} \text { : } \\
\text { very rarely }\end{array}$ & 0.000 & 0.331 \\
\hline
\end{tabular}




\begin{tabular}{|c|l|c|c|}
\hline No. & $\begin{array}{c}\text { Variables that } \\
\text { are Related }\end{array}$ & $\begin{array}{c}\text { Asymp. Sig. } \\
\text { (2-sided) }\end{array}$ & $\begin{array}{c}\text { Correlation } \\
\text { (Spearman } \\
\text { Correlation }\end{array}$ \\
\hline 16. & $\begin{array}{l}\text { Comfort - egress } \\
\text { mode choice, CV: } \\
\text { very rarely }\end{array}$ & 0.049 & 0.293 \\
\hline
\end{tabular}

Among the four walkability measures tested, walking distance and comfort are those variables that not only have direct relationships with access mode choice but also have relationships when there are control variables that affect those relationships. Control variables that affect the relationship of walking distance and comfort with access mode choice are trip purpose 'work', train usage 'very often', and 'have' (vehicle ownership). There is a difference of influence of control variable on walking distance relationship with access mode choice and between comfort with access mode choice. If the walking distance, which affects the control variable 'male', while the affecting comfort is 'female'. In addition, walking distance is influenced by age group '17 -25 ', while the comfort is influenced by age group ' $26-50$ '.

The walking distance and comfort relationship pattern from the destination station to the final destination with egress mode choice is somewhat different. There are no control variables that affect walking distance relationship with egress mode choice. Safety has a relationship with the access mode choice only when tested with the control variable 'female'. Meanwhile, for egress mode choice is related to safety when tested by control variable 'very rarely'.

Only security has no relationship with the mode choice, either on access or egress trip. It appears that the security variable is not something that the train users who departure from Cicalengka Train Station consider choosing the access or egress mode.

\section{Discussion and conclusions}

There are some interesting results to discuss. First of all, the security is not the measurement of walkability into consideration to choose the mode. This means that even if someone feels that the security from home to the origin station or from the destination station to the final destination is good, it does not necessarily want to walk. If returned to the data the number of respondents walking from home to the origin stations is relatively small $(11.3 \%)$, a good assessment of the security built environment has no effect at all. They are more likely to choose paratransit than walking.

There is a difference in the component of walkability that affects male and female in choosing access mode. If males are more affected by walking distance, then females are influenced by comfort. A similar thing happens in the control variable age group. Walking distance is chosen by the age group ' $17-25$ years', while comfort is the choice of age group ' $26-50$ years'.

For people who travel for 'work', walking distance and comfort for walking become the decider in choosing access mode. Meanwhile, there is no relationship between walking distance with access mode choice for train users who are travel for 'school', 'shopping', and for other activities. Likewise for comfort, not something important for choosing the access mode except for travelling to work. The same pattern also occurs in respondents who very often use the train. Walking distance and comfort for walking are only important for the very frequent use of trains, otherwise it does not affect anything for other train users to choose the access mode.

Another interesting finding is the existence of a relationship between walking distance with access mode choice and between comfort with access mode choice for train users, even though they have private vehicles. This means that for private vehicle owners, walking distance and comfort remains a consideration for choosing to walk or not. Despite having a vehicle, if walking distance is close and comfort is nice, they are more likely to walk than using a private vehicle.

The last interesting finding is that for respondents who are very rare using train, safety and comfort of the built environment from the destination station to the final destination are important for them when choosing a mode for egress trip. Meanwhile, for this group of respondents, none of the walkability measures were decisive in the selection of access modes.

Overall, the conclusions that can be obtained from this research are:

- Using the crosstabs analysis, found a relationship between train users' perceptions of the built environment walkability factors with the mode choice, both access and egress mode.

- Security is the only measure of walkability that has no association with the access and the egress mode choice. This finding is similar to previous study [8].

- Each variable control has a different influence in the relationship between walkability factors with access and egress mode choice.

The authors would like to thank PT KAI to allow for collecting data. The authors also would like to thank the students of Urban and Regional Planning, Unikom, Bandung, who have helped carry out the survey.

\section{References}

1. R. Daniels, C. Mulley, JTLU, 6(2), 5-20 (2013)

2. D. Hernández, R. Witter, J. Public Transp., 18(4), 16-30 (2015)

3. C. P. Durand, X. Tang, K. P., Gabriel, I. N. Sener, A. O. Oluyomi, G. Knell, A. K. Porter, D. M. Oelscher, H. W. Kohl III, J. Transp. Health, 3(2), 154-160 (2016)

4. R. Cervero, O. L. Sarmiento, E. Jacoby, L. F. Gomez, A. Neiman, Int. J. of Sust. Transp., 3, 203226 (2009)

5. A. Ozbil, Eighth International Space Syntax Symposium, 8030:1-8030:15 (2012)

6. S. Park, K. Choi, J. S. Lee, Int. J. of Sust. Transp., 9(8), 529-541 (2015) 
7. S. S. Wibowo, P. Olszewski, J. of the EASTS, 6, 147-156 (2005)

8. D. Walton, S. Sunseri, Int. J. of Sust. Transp., 4, $212-$ $226(2010)$

9. V. Van Acker, P. L. Mokhtarian, F. Witlox, EJTIR, 11(2), 115-146 (2011)

10. V. van Acker, B. Derudder, F. Witlox, JTLU, 6(1), 53-62 (2013)

11. S. Handy, X. Cao, P. L. Mokhtarian, J. APA, 72(1), 55-74 (2006)

12. X. (J) Cao, P. L. Mokhtarian, S. L. Handy, Transport Reviews, 29(3), 359-395 (2009)

13. V. Mehta, J. of Urbanism, 1(3), 217-245 (2008)

14. J. R. Panter, A. Jones, J. of Physical Act. \& Health, 7, 551-561 (2010)

15. J. Lin, T. Yu, Transport Policy, 18, 246-258 (2011)

16. A. Adkins, J. Dill, G. Luhr, M. Neal, J. of Urban Design, 17(4), 499-510 (2012) 